\title{
PENGARUH EARNING PER SHARE, RETURN ON EQUITY, PRICE EARNING RATIO, DAN DEBT TO EQUITY RATIO TERHADAP HARGA SAHAM (PERUSAHAAN YANG TERGABUNG DALAM INDEKS LQ45 DI BURSA EFEK INDONESIA)
}

\author{
Ayu Kemalasari ${ }^{1}$, Desrini Ningsih ${ }^{2}$ \\ ${ }^{1}$ Mahasiswa Program Studi Akuntansi, Universitas Putera Batam \\ ${ }^{2}$ Dosen Program Studi Akuntansi, Universitas Putera Batam \\ email: ayukem9@gmail.com
}

\begin{abstract}
This study aims to analyze the effect of Earning Per Share, Return On Equity, Price Earning Ratio, and Debt to Equity Ratio on stock price of the companies listed in the LQ45 index for the period 2013-2017. The results showed that EPS had a significant effect on stock prices with a sig value of 0,000. ROE had no significant effect on stock prices with a sig value of 0,131. PER had a significant effect on stock prices with a sig value of 0,000. DER had no significant effect on stock prices with a sig value of 0,572. EPS, ROE, PER, and DER variables simultaneously have a significant effect on stock prices with a sig value of 0,000. The determination coefficient is 0,839, which means the EPS, ROE, PER, and DER variables is $83,9 \%$ affect the stock price while the remaining $16,1 \%$ is influenced by other variables not examined in this study.
\end{abstract}

Keywords: Earning Per Share; Return On Equity; Price Earning Ratio; Debt to Equity Ratio; and Stock Price.

\section{PENDAHULUAN}

Pasar modal merupakan salah satu media efektif bagi suatu negara di era ekonomi digital seperti saat ini, termasuk dalam hal memperlekas pembangunan suatu negara. Seperti yang kita ketahui, pembangunan suatu negara menghabiskan modal yang tidak sedikit, risiko yang rendah, dan memerlukan dana jangka panjang. Untuk itulah kehadiran pasar modal menjadi salah satu cara efektif untuk mendapatkan pembiayaan jangka panjang bagi masyarakat. Pasar modal merupakan wadah yang tepat bagi lembaga perbankan maupun non perbankan untuk berinvestasi. Dengan adanya pasar modal perusahaan-perusahaan dapat mencetak saham yang dapat memberikan banyak manfaat salah satunya ialah memperoleh sumber pendanaan baru dengan cara melakukan perdagangan saham kepada publik. Dengan melakukan perdagangan saham kepada publik maka perusahaan sudah dapat dikatakan sebagai perusahaan Go Public yang nantinya banyak dikenal oleh masyarakat dan hal ini merupakan salah satu jalan yang cukup baik untuk meningkatkan nilai perusahaan.

Penelitian ini memakai Indeks LQ45 (ILQ45) sebagai objek penelitian. Harga saham selalu mengalami pasang surut (fluktuasi), ini menyiratkan bahwa perusahaan yang terdaftar pada ILQ45 juga ikut mengalami fluktuasi meskipun ILQ45 sering disebut sebagai saham terbaik (blue chip). Tinggi rendahnya harga saham perusahaan yang terdapat dalam ILQ45 selama 5 tahun dapat dilihat pada tabel di bawah ini: 
Tabel 1. Harga Saham Tahun 2013-2017

\begin{tabular}{llrrrrr}
\hline \multirow{2}{*}{ No } & \multicolumn{1}{c}{ Nama Perusahaan } & \multicolumn{5}{c}{ Harga Saham (Rupiah) } \\
& & 2013 & 2014 & 2015 & 2016 & 2017 \\
\hline 1. & Adhi Karya Persero (Persero) Tbk. & 1.281 & 2.953 & 2.140 & 2.080 & 1.885 \\
2. & Adaro Energy Tbk. & 1.090 & 1.040 & 515 & 1.695 & 1.860 \\
3. & AKR Corporindo Tbk. & 4.375 & 4.120 & 7.175 & 6.000 & 6.350 \\
4. & Aneka Tambang (Persero) Tbk. & 916 & 895 & 314 & 895 & 625 \\
5. & Astra International Tbk. & 6.800 & 7.425 & 6.000 & 8.275 & 8.300 \\
& & & & & &
\end{tabular}

Tabel di atas menjelaskan bahwa harga saham pada perusahaan yang tergabung dalam ILQ45 setiap tahunnya terus mengalami pasang surut dari tahun 2013-2017. Harga saham tertinggi dimiliki oleh PT Astra International di tahun 2017 sejumlah Rp 8.300, sedangkan harga saham terendah dimiliki oleh PT Aneka Tambang pada tahun 2015 sejumlah Rp 314. Hal ini mengisyaratkan bahwa terdapat banyak faktor yang dapat mempengaruhi pasang surutnya harga saham seperti kebijakan pemerintah, melemahnya rupiah serta faktor lainnya. Kebanyakan investor akan mengukur kinerja perusahaan sebelum berinvestasi agar dapat menilai baik buruknya keputusan yang akan diambil dengan cara mengkaji rasio keuangan. Secara sederhana dapat dikatakan bahwa dengan mengkaji laporan keuangan maka dapat diketahui tingkat risiko dan profitabilitas suatu perusahaan di tempat investor tersebut akan berinvestasi.

Melalui rasio keuangan, para pengguna dapat mengukur dan menelaah laporan kinerja perusahaan melalui laporan keuangan yang terdiri dari laporan laba rugi, neraca, arus kas, perubahan modal, dan catatan atas laporan keuangan. Dengan adanya laporan keuangan maka diharapkan dapat menolong para pengguna laporan keuangan agar terhindar dari analisis yang keliru. Pengguna laporan keuangan terdiri dari pemerintah, investor, calon investor, kreditur, calon kreditur, dan pihak berkepentingan lainnya. Para pengguna tersebut menggunakan laporan keuangan untuk mengambil keputusan jangka panjang maupun pendek.

Para investor menggunakan EPS agar dapat mengkaji kemampuan perusahaan dalam memperoleh profit. Informasi EPS dapat menggambarkan keberhasilan suatu perusahaan dan seberapa besar tingkat keuntungan yang akan diperoleh investor. Semakin tinggi EPS maka akan dapat menghadirkan keuntungan yang cukup menyenangkan hati para investor, sehingga investor akan lebih terpacu untuk berinvestasi di perusahaan tersebut yang akan menjadikan harga saham tersebut melambung tinggi. Untuk dapat mengetahui kesanggupan perusahaan dalam memperoleh profit berdasarkan modal yang diinvestasikan oleh para investor maka dapat dilakukan dengan menganalisis ROE. Semakin tinggi ROE maka laba bersih yang dihasilkan akan semakin tinggi yang akan menghadiahkan dampak positif bagi perusahaan ialah semakin banyaknya investor yang akan tertarik untuk menanamkan modalnya yang nantinya harga saham perusahaan tersebut akan melambung jauh.

Para investor menggunakan PER untuk meninjau bagaimana kinerja perusahaan pada masa lampau dan untuk meninjau perkembangan perusahaan apakah mempunyai pertumbuhan yang tinggi atau justru sebaliknya. Secara sederhana dapat dikatakan bahwa dengan menelaah PER maka para investor akan mengetahui apakah harga saham perusaahan tersebut masih tergolong wajar atau tidak. Semakin tinggi PER maka diharapkan pertumbuhan laba suatu perusahaan juga akan meningkat.

Dengan mengkaji DER maka para investor dapat mengukur tingkat utang yang dimiliki perusahaan. Secara umum dikatakan bahwa perusahaan yang tumbuh biasanya akan memiliki utang untuk keperluan pendanaannya dalam menjalankan perusahaan dengan memiliki tingkat utang yang tinggi dapat memberikan peluang bagi perusahaan untuk mendapatkan laba yang 
tinggi. Namun, utang yang terlalu tinggi juga tidak baik untuk perusahaan karena ditakutkan perusahaan tidak mampu membayar utangnya.

\section{TINJAUAN PUSTAKA}

\section{Harga Saham}

Harga yang berlaku pada waktu tertentu yang ditetapkan oleh pelaku pasar dan ditentukan oleh permintaan dan penawaran saham yang bersangkutan di pasar bursa disebut harga saham (Hartono, 2017:208).

Kertas berharga yang didalamnya dicantumkan dengan jelas nilai nominal, nama perusahaan serta hak dan kewajiban setiap pemegang saham disebut saham (Fahmi, 2015:80).

\section{Earning Per Share (EPS)}

Besarnya pemulangan modal untuk setiap satu lembar saham biasa diukur melalui pendapatan per saham (EPS). Pemegang saham, calon pemegang saham, serta manajemen umumnya berminat terhadap pendapatan per saham (Sumarsan, 2017:53).

EPS terbagi menjadi dua jenis yaitu EPS primer (primary EPS) dan EPS yang disesuaikan (fully diluted EPS) (Hanafi \& Halim, 2016:187).

\section{Return On Equity (ROE)}

Untuk menghitung laba yang dihasilkan perusahaan untuk diberi kepada pemegang saham dengan terlebih dahulu memperhitungkan bunga dan dividen saham preferen disebut ROE. Secara sederhana dapat dikatakan bahwa dengan melihat ROE maka para investor dapat mengetahui mampu atau tidaknya perusahaan mendatangkan laba untuk keuntungan pemegang saham (Hanafi \& Halim, 2016:178).

\section{Price Earning Ratio (PER)}

Suatu rasio yang digunakan investor untuk menaksir bagaimana kemungkinan pertumbuhan perusahaan di waktu yang akan datang dan merepresentasikan harga saham yang bersedia dibayar oleh investor untuk setiap rupiah keuntungan yang didapatkan disebut PER (Sudana, 2015:26).

\section{Debt to Equity Ratio (DER)}

Tingkatan dana yang mampu mengindikasikan dana yang disiapkan pihak pemegang saham kepada pemberi pinjaman dapat diukur dengan rasio DER. Semakin meningkat DER akan berdampak pada semakin rendahnya dana yang disiapkan oleh pemegang saham dan sebaliknya (Sumarsan, 2017:47).

\section{Penelitian Terdahulu}

Hasil penelitian yang dilakukan oleh (Faradillah, 2017) menerangkan bahwa variabel EPS, ROE, dan DER, secara simultan berpengaruh signifikan terhadap harga saham. Variabel EPS secara parsial berpengaruh signifikan terhadap harga saham. Variabel ROE secara parsial tidak berpengaruh signifikan terhadap harga saham. Variabel DER secara parsial berpengaruh terhadap harga saham.

Penelitian yang dilakukan oleh (Aletheari \& Jati, 2016) menerangkan bahwa secara simultan, EPS, PER, dan BVS berpengaruh positif terhadap harga saham. EPS, PER, dan BVS tersebut juga berpengaruh pada harga saham secara parsial.

\section{Hipotesis}

Hipotesis yang terdapat dalam penelitian ini adalah sebagai berikut:

$\mathrm{H}_{1}$ : EPS berpengaruh signifikan terhadap harga saham .

$\mathrm{H}_{2}$ : ROE berpengaruh signifikan terhadap harga saham.

$\mathrm{H}_{3}$ : PER berpengaruh signifikan terhadap harga saham.

$\mathrm{H}_{4}$ : DER berpengaruh signifikan terhadap harga saham. 
$\mathrm{H}_{5}$ : EPS, ROE, PER, DER secara simultan berpengaruh signifikan terhadap harga saham.

\section{METODE}

Penelitian ini menggunakan data sekunder. Disebut data sekunder sebab data yang digunakan tidak perlu diolah kembali karena data yang diperoleh berasal dari lembaga atau pihak yang telah mempublikasikan. Jadi, jika ditemukan kesalahan atau ketidakakuratan data maka hal itu tidak menjadi tanggung jawab sang peneliti atau dengan kata lain yang akan bertanggung jawab ialah lembaga yang menggunakan dan mempublikasikannya (Chandrarin, 2017:124).

Penetapan sampel di penelitian ini memakai metode Purposive Sampling. Populasi di penelitian ini berjumlah 45. Dari penyaringan sampel yang telah dilakukan diperoleh sampel sebanyak 12 selama 5 tahun periode 2013-2017. Pengolahan data dilakukan dengan alat uji SPSS versi 20.

\section{HASIL DAN PEMBAHASAN} Analisis Deskriptif

Tabel 2. Statistik Deskriptif

\begin{tabular}{lccccc}
\hline \multicolumn{5}{c}{ Descriptive Statistics } \\
\hline EPS & $\mathrm{N}$ & Minimum & Maximum & Mean & Std. Deviation \\
ROE & 60 & .09 & 479.63 & 158.6973 & 116.45607 \\
PER & 60 & 2.87 & 46.10 & 17.2917 & 9.81951 \\
DER & 60 & 7.83 & 44.75 & 21.6918 & 9.44473 \\
Harga Saham & 60 & .20 & 5.26 & 1.0585 & 1.00997 \\
Valid N (listwise) & 60 & 488 & 8300 & 2928.88 & 1992.009 \\
\end{tabular}

Jumlah data di penelitian ini sejumlah 60 data. Variabel EPS memiliki angka terendah 0,09 dan angka tertinggi 479,63 dengan rata-rata sejumlah 158,6973 serta standar deviasinya sejumlah 116,45607 .

Variabel ROE memiliki angka terendah 2,87 dan angka tertinggi 46,10 dengan rata-rata sejumlah 17,2917 serta standar deviasinya sejumlah 9,81951.

Variabel PER memiliki angka terendah 7,83 dan angka tertinggi 44,75 dengan rata-rata sejumlah 21,6918 serta standar deviasinya sejumlah 9,44473.

Variabel DER memiliki angka terendah 0,20 dan angka tertinggi 5,26 dengan rata-rata sejumlah 1,0585 serta standar deviasinya sejumlah 1,00997.

Variabel harga saham memiliki angka terendah 488 dan angka tertinggi 8300 dengan nilai rata-rata sejumlah 2928,88 serta standar deviasinya sebanyak 1992,009 
Hasil Uji Asumsi Klasik Hasil Uji Normalitas



Gambar 1. Uji Histogram

Normal P-P Plot of Regression Standardized Residual

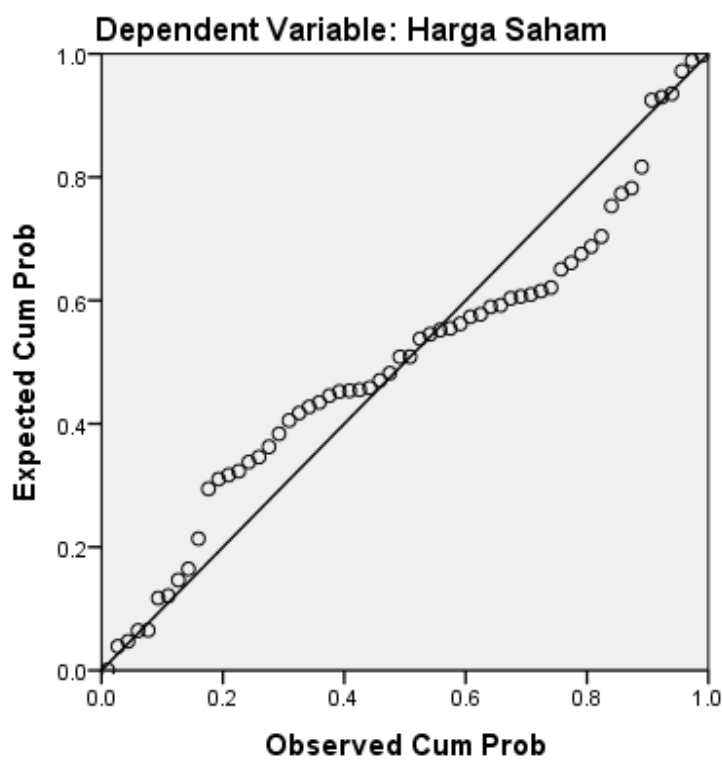

Gambar 2. Uji Normal P-Plot of regression

Dengan melihat gambar 1 dan 2 di atas yang menggambarkan bentuk kurva yang berbentuk lonceng (bell-shaped curve) dengan memakai uji histogram dan posisi titik-titik yang menyebar mengikuti garis diagonalnya dengan memakai uji p-plot simpulan yang diambil ialah data berdistribusi normal. 
Tabel 3. One Sample Kolmogorov Smirnov

One-Sample Kolmogorov-Smirnov Test

Unstandardized Residual

$\begin{array}{llr}\text { N } & & 60 \\ \text { Normal Parameters }^{\mathrm{a}, \mathrm{b}} & \text { Mean } & 0 \mathrm{E}-7 \\ & \begin{array}{l}\text { Std. } \\ \text { Deviation }\end{array} & 771.57909769 \\ & \text { Absolute } & .125 \\ \text { Most Extreme Differences } & \text { Positive } & .125 \\ \text { Kolmogorov-Smirnov Z } & \text { Negative } & -.121 \\ \text { Asymp. Sig. (2-tailed) } & & .968 \\ \text { a. Test distribution is Normal. } & & .306 \\ \text { b. Calculated from data. } & & \end{array}$

Untuk mencegah kesalahan pengambilan keputusan maka diperlukan juga uji statistik lain yang dapat memberikan hasil yang lebih akurat yaitu One Sample Kolmogorv Smirnov. Tabel 3 mengungkapkan bahwa nilai signifikansi sejumlah $0,306>$ alpha 0,05 jadi simpulannya ialah data berdistribusi normal.

\section{Uji Multikolinearitas}

Dengan melihat nilai VIF dan tolerance maka dapat diketahui ada tidaknya gejala multikolinearitas pada model regresi.

Tabel 4. Uji Multikolinearitas

\begin{tabular}{lcc}
\hline Model & Collinearity Statistics & \\
& Tolerance & \\
\hline 1 (Constant) & & \\
EPS & .881 & 1.135 \\
ROE & .903 & 1.107 \\
PER & .818 & 1.223 \\
DER & .957 & 1.045 \\
a. Dependent Variable: Harga Saham & & \\
\hline
\end{tabular}

Tabel 4 mengungkapkan bahwa variabel EPS mempunyai angka tolerance sejumlah 0,881 dan VIF sejumlah 1,135. Variabel ROE memiliki angka tolerance sejumlah 0,903 dan VIF 1,107. Variabel PER memiliki angka tolerance 0,818 dan nilai VIF 1,223 . Variabel DER memiliki angka tolerance 0,957 dan nilai VIF 1,045. Dari hasil uji multikolinearitas di atas dapat diambil kesimpulan bahwa dalam penelitian ini tidak terjadi multikolinearitas. Hal ini bisa disimpulkan sebab angka tolerance dalam penelitian ini $\geq$ 0,10 dan angka $\mathrm{VIF} \leq 10$. 


\section{Uji Heteroskedastisitas}

Tabel 5. Uji Glejser



a. Dependent Variable: Abresid

Hasil tabel 5 menyirartkan bahwa nilai signifikansi masing-masing variabel ialah sejumlah 1,000 yang mempunyai arti bahwa 1,000 lebih tinggi daripada 0,05 jadi simpulannya ialah data penelitian ini tidak mengalami heteroskedastisitas.

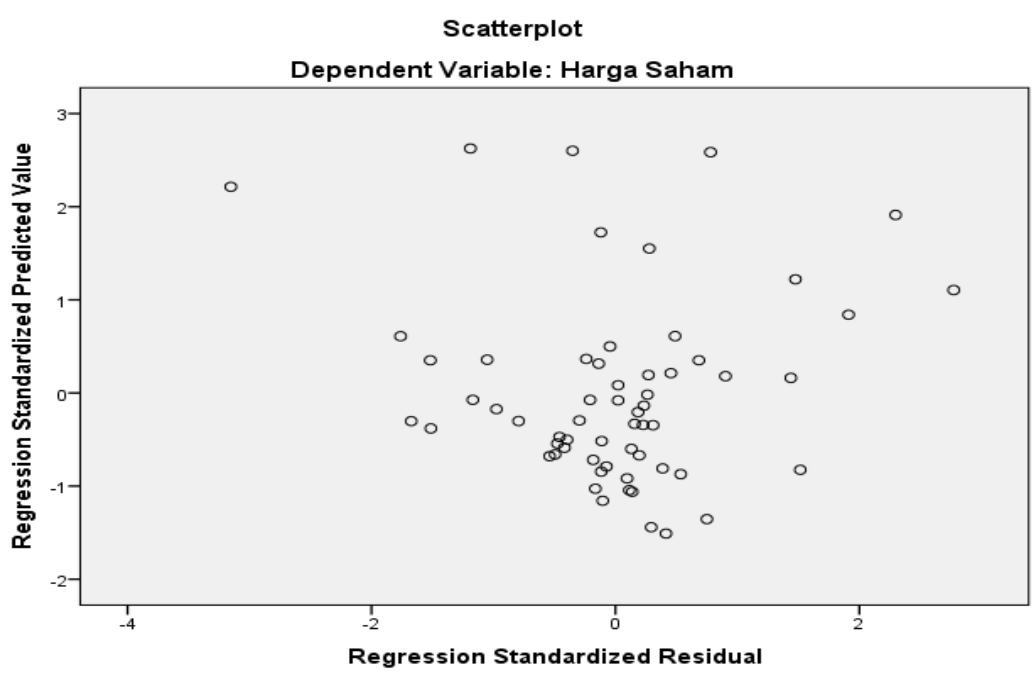

Gambar 3. Scatterplot

Gambar di atas memperlihatkan bahwa tidak ada heteroskedastisitas sebab titik-titik telah menyebar di atas dan di bawah atau di sekitar angka 0 serta penyebaran titik-titik tidak berpola.

\section{Uji Autokorelasi}

Tabel 6. Uji Autokorelasi

\begin{tabular}{|c|c|c|c|c|c|}
\hline \multicolumn{6}{|c|}{ Model Summary } \\
\hline Model & $\mathrm{R}$ & R Square & $\begin{array}{l}\text { Adjusted R } \\
\text { Square }\end{array}$ & $\begin{array}{l}\text { Std. Error of the } \\
\text { Estimate }\end{array}$ & Durbin-Watson \\
\hline
\end{tabular}




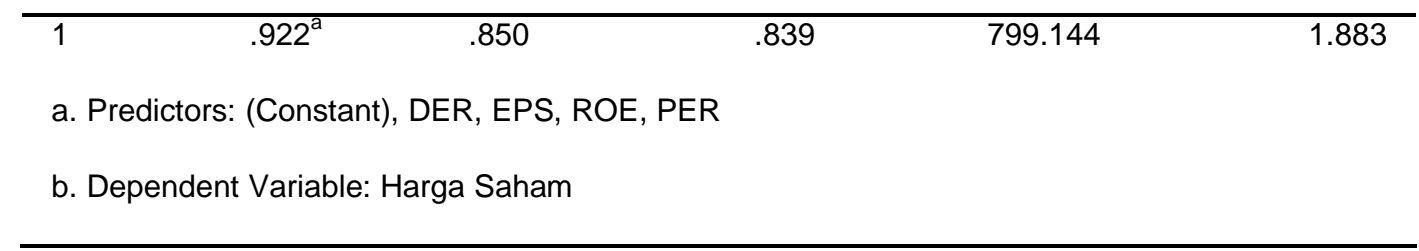

Berdasarkan tabel 6 diperoleh nilai d hitung (DW) sejumlah 1,883 dengan $\mathrm{k}=4$ dan $\mathrm{n}=60$ maka diperoleh nilai DW untuk dL sejumlah 1,4443 dan dU sebesar 1,7274. Maka, $d u<\mathrm{d}$ hitung $<4-d u$ diperoleh $1,7274<1,883<2,2726$ jadi simpulannya ialah tidak ada autokorelasi.

\section{Analisis Regresi Linear Berganda}

Tabel 7. Analisis Regresi Linear Berganda Coefficients $^{a}$

\begin{tabular}{cccccc} 
Model & \multicolumn{2}{c}{ Unstandardized Coefficients } & $\begin{array}{c}\text { Standardized } \\
\text { Coefficients }\end{array}$ & T & Sig. \\
& & B & Std. Error & Beta & \\
\hline 1 & (Constant) & -1347.499 & 371.740 & -3.625 & .001 \\
EPS & 16.378 & .952 & .957 & 17.207 & .000 \\
ROE & 17.094 & 11.149 & .084 & 1.533 & .131 \\
PER & 66.617 & 12.180 & .316 & 5.469 & .000 \\
DER & -59.888 & 105.292 & -.030 & -.569 & .572
\end{tabular}

a. Dependent Variable: Harga Saham

Persamaan regresi yang dapat dirumuskan ialah:

$\mathrm{Y}=-1347,499+16,378 \mathrm{X}_{1}+17,094 \mathrm{X}_{2}+\quad 66,617 \mathrm{X}_{3}+(-59,888) \mathrm{X}_{4}$

Nilai konstanta memperlihatkan angka sejumlah -1347,499 berarti jika EPS, ROE, PER, dan DER nilainya 0, maka nilai harga saham ialah sejumlah -1347,499.

EPS memiliki nilai koefisien regresi sejumlah 16,378. Apabila variabel independen lainnya tetap dan nilai EPS naik 1\% maka harga saham akan mengalami kenaikan sejumlah 16,378.

ROE memiliki nilai koefisien regresi sejumlah 18,094. Apabila variabel independen lainnya tetap dan nilai ROE naik 1\% maka harga saham akan mengalami kenaikan sejumlah 18,094.

PER memiliki nilai koefisien regresi sejumlah 66,617 berarti jika variabel independen lainnya tetap dan nilai PER naik 1\% maka harga saham akan bertambah sejumlah 66,617.

DER memiliki nilai koefisien regresi sejumlah $-59,888$ artinya jika variabel independen lainnya tetap dan nilai DER naik 1\% maka harga saham akan mengalami berkurang sejumlah 59,888. 


\section{Uji Hipotesis}

\section{Uji t (Secara Parsial)}

Jika $t_{\text {hitung }} \leq t_{\text {tabel }}$ atau sig $>0,05$ maka $H_{0}$ diterima dan apabila $t_{\text {hitung }}>t_{\text {tabel }}$ atau $\operatorname{sig} \leq 0,05$ maka $H_{0}$ ditolak.

Tabel 8. Uji t

Coefficients

\begin{tabular}{|c|c|c|c|c|c|c|}
\hline \multirow[t]{2}{*}{ Mode } & & \multicolumn{2}{|c|}{ Unstandardized Coefficients } & \multirow{2}{*}{$\begin{array}{c}\text { Standardized } \\
\text { Coefficients } \\
\text { Beta }\end{array}$} & \multirow[t]{2}{*}{$\mathrm{T}$} & \multirow[t]{2}{*}{ Sig. } \\
\hline & & B & Std. Error & & & \\
\hline \multirow[t]{5}{*}{1} & (Constant) & -1347.499 & 371.740 & & -3.625 & .001 \\
\hline & EPS & 16.378 & .952 & .957 & 17.207 & .000 \\
\hline & ROE & 17.094 & 11.149 & .084 & 1.533 & .131 \\
\hline & PER & 66.617 & 12.180 & .316 & 5.469 & .000 \\
\hline & DER & -59.888 & 105.292 & -.030 & -.569 & .572 \\
\hline
\end{tabular}

a. Dependent Variable: Harga Saham

$\mathrm{T}_{\text {tabel }}$ dihitung dengan rumus $\mathrm{df}=\mathrm{n}-\mathrm{k}-1$ maka $\mathrm{df}=60-4-1=55$ dengan tingkat signifikansi sejumlah 5\%. Dengan df sejumlah 55 maka diperoleh nilai $t_{\text {tabel }}$ yakni 2,004.

EPS memiliki nilai $t_{\text {hitung }} 17,207>\mathrm{t}_{\text {tabel }} 2,004$ dan nilai sig $0,000<$ alpha 0,05 maka $\mathrm{H}_{1}$ diterima. ROE memiliki nilai $t_{\text {hitung }} 1,533<\mathrm{t}_{\text {tabel }} 2,004$ dan nilai sig $0,131>$ alpha 0,05 maka $\mathrm{H}_{2}$ ditolak. PER memiliki nilai $\mathrm{t}_{\text {hitung }} 5,469>\mathrm{t}_{\text {tabel }} 2,004$ dan nilai sig $0,000<$ alpha $0,05 \mathrm{H}_{3}$ diterima. DER memiliki nilai $\mathrm{t}_{\text {hitung }}-0,569>\mathrm{t}_{\text {tabel }}-2,004$ dan nilai sig $0,572>$ alpha 0,05 maka $\mathrm{H}_{4}$ ditolak.

Simpulannya ialah variabel EPS dan PER berpengaruh signifikan terhadap harga saham sedangkan variabel ROE dan DER tidak berpengaruh signifikan terhadap harga saham.

\section{Uji F (Secara Simultan)}

Jika $\mathrm{F}_{\text {hitung }} \leq \mathrm{F}_{\text {tabel }}$ atau sig $>0,05$ maka $\mathrm{H}_{\mathrm{o}}$ diterima dan apabila $\mathrm{F}_{\text {hitung }}>\mathrm{F}_{\text {tabel }}$ atau $\operatorname{sig} \leq 0,05$ maka $\mathrm{H}_{\mathrm{o}}$ ditolak.

Tabel 9. Uji F

ANOVA $^{\text {a }}$

\begin{tabular}{lrrrrrr}
\multicolumn{1}{c}{ Model } & Sum of Squares & Df & Mean Square & F & Sig. \\
\hline 1 & Regression & 198993150.248 & 4 & 49748287.562 & 77.898 & $.000^{D}$ \\
& Residual & 35124723.935 & 55 & 638631.344 & & \\
& Total & 234117874.183 & 59 & &
\end{tabular}
a. Dependent Variable: Harga Saham
b. Predictors: (Constant), DER, EPS, ROE, PER

$\mathrm{F}_{\text {tabel }}$ dihitung dengan rumus $\mathrm{df}(\mathrm{n} 1)=$ jumlah variabel (independen dan dependen) $-1=5-1=4$ dan df (n2) = n-k-1 maka df = 60-4-1 = 55 dengan tingkat signifikansi sejumlah 5\%. Dengan df (n1) dan df (n2) sejumlah 4 dan 55 maka didapat nilai $F_{\text {tabel }}$ sejumlah 2,540. Nilai $F_{\text {hitung }} 77,898>F_{\text {tabel }} 2,540$ dan nilai sig 0,000 < alpha 0,05 maka, EPS, ROE, PER, dan DER secara simultan berpengaruh signifikan terhadap harga saham 
Koefisien Determinasi $\left(\mathbf{R}^{2}\right)$

Tabel 10. Koefisien Determinasi

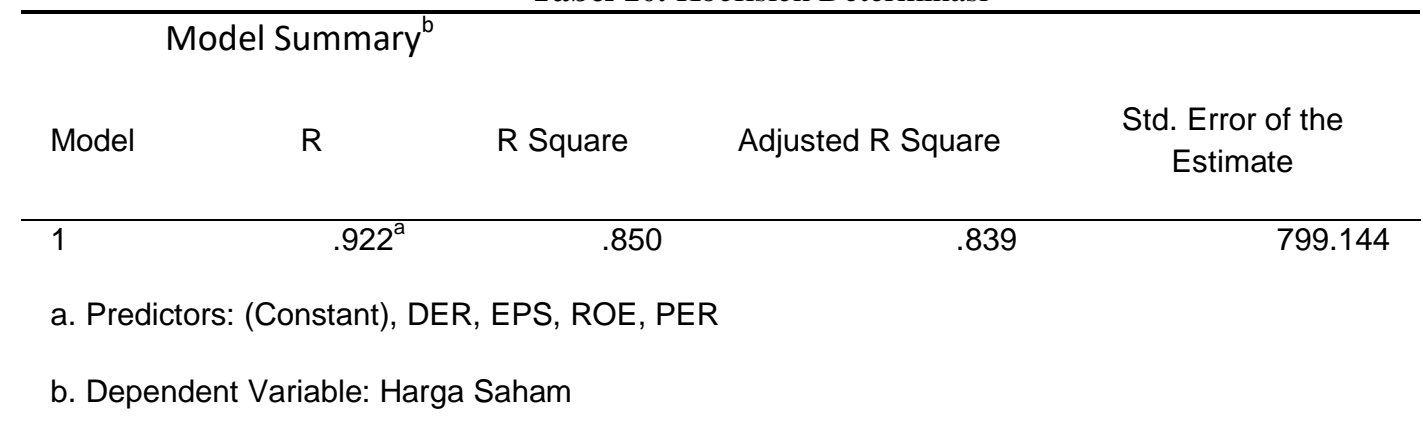

Nilai koefisien determinasi sejumlah 0,839 menjelaskan bahwa variabel EPS, ROE, PER, dan DER mempengaruhi harga saham sejumlah $83,9 \%$ sedangkan sisanya sejumlah $16,1 \%$ dipengaruhi oleh variabel lain yang tidak diteliti dalam penelitian ini.

\section{Pengaruh EPS Terhadap Harga Saham}

Pengolahan data yang dilakukan memperoleh simpulan yaitu $\mathrm{H}_{1}$ diterima. EPS lazimnya dipakai dalam hal menilai tingkat kesuksesan perusahaan untuk mendatangkan laba dalam memberikan keuntungan untuk para pemegang saham biasanya. Kaitan EPS dengan harga saham ialah berpengaruh signifikan yang artinya apabila EPS mengalami peningkatan maka harga saham juga akan mengalami peningkatan, sebaliknya jika EPS mengalami penurunan maka harga saham juga akan mengalami penurunan. Artinya, EPS yang tinggi akan memberikan pengembalian yang tinggi pula sehingga para investor tertarik untuk memiliki saham perusahaan tersebut yang akan menjadikan harga saham melonjak. Hasil penelitian ini memperlihatkan bahwa EPS merupakan salah satu alat ukur yang diminati oleh para investor dalam mengambil keputusan sebelum berinvestasi sebab investor cenderung melihat EPS untuk memperkirakan keuntungan yang akan didapatnya.

\section{Pengaruh ROE Terhadap Harga Saham}

Pengolahan data yang dilakukan memperoleh simpulan yaitu $\mathrm{H}_{2}$ ditolak. Bagi pemegang saham ROE merupakan alat ukur untuk mengkaji tingkat pengembalian yang akan diterimanya dari modal yang ditanamkan. Hasil peneltian ini memperlihatkan bahwa tingkat pengembalian yang diterima investor masih tergolong rendah sehingga tidak dapat menarik investor yang mengakibatkan harga saham mengalami penurunan. Sehingga tampak bahwa kemampuan perusahaan dalam mengelola ekuitasnya masih tergolong rendah. Hasil penelitian ini memberitahukan bahwa ROE tidak ada pengaruh terhadap harga saham.

Hal ini terbukti melalui data perusahaan dalam penelitian ini salah satunya pada PT AKR Corporindo Tbk. (AKRA) pada tahun 2013-2017 yang mengalami peningkatan dan penurunan harga saham dan diikuti oleh ROE yang mengalami naik turun. Pada tahun 2013 nilai ROE PT AKRA sejumlah $11,48 \%$ dengan harga saham Rp 4.375. Pada tahun 2014 nilai ROE naik sejumlah 13,26\% dengan diikuti penurunan harga saham menjadi Rp 1.040. Pada tahun 2015 nilai ROE sejumlah 14,53\% dengan diikuti kenaikan harga saham sejumlah Rp 7.175. Pada tahun 2016 nilai ROE menurun sejumlah 12,97\% diikuti dengan turunnya harga saham, sedangkan pada tahun 2017 nilai ROE sejumlah 14,45\% dengan harga saham sejumlah $\mathrm{Rp}$ 6.350. Jadi simpulannya ialah naik turunnya harga saham tidak tergantung pada tinggi rendahnya nilai ROE.

\section{Pengaruh PER Terhadap Harga Saham}

Pengolahan data yang dilakukan memperoleh simpulan yaitu $\mathrm{H}_{3}$ diterima. Dalam hal mengukur pertumbuhan perusahaan salah satu rasio yang dapat digunakan yaitu PER, tinggi rendahnya PER akan mempengaruhi pertumbuhan perusahaan apakah akan meningkat atau justru mengalami penurunan. Pertumbuhan perusahaan yang tinggi dapat menggambarkan bahwa perusahaan mampu mendapatkan laba yang cukup tinggi. Laba perusahaan yang tinggi tersebut membuat investor yakin akan mendapatkan pengembalian yang tinggi dari setiap rupiah yang mereka investasikan. Hal tersebut dapat menarik para investor untuk berinvestasi. Hasil penelitian ini mengatakan bahwa PER ada pengaruh terhadap harga saham, berarti semakin tinggi PER maka harga saham meningkat. 


\section{Pengaruh DER Terhadap Harga Saham}

Pengolahan data yang dilakukan memperoleh simpulan yaitu $\mathrm{H}_{4}$. DER ialah sebuah rasio untuk memperkirakan tingkat utang yang dimiliki perusahaan. Semakin tinggi DER maka tingkat utang juga akan meningkat. Tingginya tingkat utang akan memberikan efek pada tingginya risiko yang akan ditanggung perusahaan. Hal ini akan berdampak pada kurangnya minat investor untuk berinvestasi akibatnya harga saham juga akan ikut memburuk. Para investor cenderung menjauhi perusahaan dengan DER yang tinggi dikarenakan ketika perusahaan memperoleh laba tersebut akan digunakan untuk melunasi tunggakannya terlebih dahulu dibandingkan memenuhi kewajibannya kepada pemegang saham yang akan memberikan dampak tingkat pengembalian yang rendah pada pemegang saham. Namun dalam beberapa situasi, DER yang tinggi akan mendatangkan tingkat pengembalian yang cukup tinggi pula. Hal ini biasanya terjadi pada perusahaan yang sedang dalam masa pertumbuhan. Biasanya beberapa investor yang tidak terlalu mempertimbangkan tinggi rendahnya DER dan siap menerima risiko tertarik untuk berinvestasi pada perusahaan tersebut. Sebab mereka yakin bahwa perusahaan mampu melunasi tunggakan dan memenuhi tanggung jawabnya kepada pemegang saham. Namun tetap saja DER yang terlalu tinggi tidak baik bagi perusahaan. Dikhawatirkan perusahaan tidak mampu melunasi seluruh kewajibannya baik kepada kreditor maupun investor. Jadi simpulannya ialah DER bukan merupakan suatu alat ukur yang diminati oleh investor dalam pengambilan keputusan sebelum berinvestasi.

\section{Pengaruh EPS, ROE, PER, dan DER Terhadap Harga Saham}

Pengolahan data yang dilakukan memperoleh kesimpulan bahwa $\mathrm{H}_{5}$ diterima. Situasi yang bisa mempengaruhi naik turunnya harga saham menurut (Fahmi, 2015:86) salah satunya ialah penurunan kinerja perusahaan yang terus menerus. Kinerja suatu perusahaan dapat dilihat dari laporan keuangan yang dihasilkan oleh perusahaan dengan mengkaji rasio keuangan. Kinerja perusahaan yang baik maka akan menerbitkan laporan keuangan yang baik pula sehingga hal ini dapat menarik hati investor. Kinerja perusahaan dapat dijadikan sebagai acuan dalam evaluasi keberhasilan suatu manajemen dan memudahkan para investor untuk mengangkat keputusan. Kinerja perusahaan yang semakin meningkat merepresentasikan bahwa perusahaan memiliki pertumbuhan yang baik hal tersebut akan berpengaruh pada naiknya harga saham sebab semakin banyaknya investor yang berminat untuk berinvestasi pada perusahaan tersebut.

\section{SIMPULAN}

1. EPS berpengaruh signifikan terhadap harga saham.

2. ROE tidak berpengaruh signifikan terhadap harga saham.

3. PER berpengaruh signifikan terhadap harga saham.

4. DER tidak berpengaruh signifikan terhadap harga saham.

5. EPS, ROE, PER dan DER secara simultan berpengaruh signifikan terhadap harga saham.

\section{DAFTAR PUSTAKA}

Aletheari, I. A. M., \& Jati, I. K. (2016). Pengaruh Earning Per Share, Price Earning Ratio, dan Book Value Per Share Pada Harga Saham. E-Jurnal Akuntansi Universitas Udayana, 17(2), 1254-1282. Chandrarin, G. (2017). Metode Riset Akuntansi Pendekatan Kuantitatif. Jakarta Selatan: Salemba Empat. Fahmi, I. (2015). Manajemen Investasi Teori dan Soal Jawab (Edisi 2). Jakarta: Salemba Empat.

Faradillah, N. (2017). Pengaruh EPS, ROE Dan DER Terhadap Harga Saham Pada Perusahaan Sub Sektor Konstruksi Bangunan Di Bursa Efek Indonesia. EJournal Administrasi Bisnis, 5(4), 972985.

Hanafi, M. M., \& Halim, A. (2016). Analisis Laporan Keuangan (5th ed.). Yogyakarta: UPP STIM YKPN.

Hartono, J. (2017). Teori Portofolio dan Analisis Investasi (11th ed.). Yogyakarta: BPFE.

Sudana, I. M. (2015). Manajemen Keuangan Perusahaan: Teori dan Praktek (Edisi 2). Jakarta: Erlangga. Sumarsan, T. (2017). Sistem Pengendalian Manajemen: Konsep, Aplikasi dan Pengkuruan Kinerja (Edisi 2). Jakarta Barat: Indeks. 